\title{
Aroma-Active Components in Wild and Cultured Sweet Smelts Fed with Various Diets
}

*Yong-Jun $\mathrm{CHA}^{1}$, Woo-Jin $\mathrm{CHO}^{1}$, So-Jung $\mathrm{KIM}^{1}$, Young-Mi $\mathrm{LEE}^{1}$, Yeon-Jung JUNG ${ }^{1}$, Eun-Jeong JEONG ${ }^{1}$, Hun $\mathrm{KIM}^{1}$, Soo-Kyung MOON ${ }^{2}$ AND Bo-Young JEONG ${ }^{2}$

$'$ Dept. of Food and Nutrition, Changwon National University, 641-773, Changwon, South Korea (yjcha@sarim.changwon.ac.kr), and ${ }^{2}$ Dept. of Food Science/Institute of Marine Industry, Gyeongsang National University, 650-160, Tongyeong, South Korea

KEY WORDS: cultured sweet smelt, aroma-active components, olfactometry analysis, diets

\section{INTRODUCTION}

Sweet smelt (Plescoglossus altivelis), having a characteristic watermelon aroma, has been favored by Koreans and Japanese for centuries. In particular, the cultured one harvested in Korea has been increased with developing aquaculture technology in recently years. However, flavor qualities of the cultured fish in Korea are slightly inferior comparing to that of fish in Japan in terms of skin color and desirable aroma such as watermelon. For enhancing the quality of cultured one in Korea, rearing sweet smelt with various diets which composed mainly of PUFA such as $18: 3 n-3$, 20:5n-3 and $22: 6 n-3$ were attempted by Jeong et al. ${ }^{1)}$

The objective of this study is to identify and compare aroma-active components in the wild and cultured ones fed with various diets for 4 weeks as a series of studies on improving quality of cultured sweet smelt.

\section{MATERIALS AND METHODS}

Cultured sweet smelts, weighing of $40 \mathrm{~g}$ each, were reared with 4 diet groups in concrete tanks $(5,000 \mathrm{~L}$ each) for 4 weeks. Four experimental white fish mealbased diets were designed as follows; a control diet (C) was added soybean oil ( $2 \%$ ) which is used as supplementary oil in Korea, a diet (CA) supplemented with an alga Enteromorpha compressa meal (2\%) to control diet, a diet (CP) added perilla oil (2\%) as lipid source instead of soybean oil and a diet (CPA) supplemented with the alga meal $(2 \%)$ and perilla oil (2\%). More details were described in a previous paper. ${ }^{1)}$ Volatile flavor compounds of sample were extracted by liquid liquid continuous extraction (LLCE) method. Details are described by Cha $e t a l^{2)}$ Extractions were performed in duplicate. Flavor analysis from LLCE extract was performed by GC/MS. Details of GC/MSD procedure have been described elsewhere. ${ }^{3)}$ Duplicated analyses were performed on each LLCE extract. For detecting of aroma-active components in LLCE extract of sample (1:3 diluted with diethyl ether), GC/olfactometry (GC/O) was performed on each extract by three trained panelists. Panelists were asked to assign odor properties and rate odor intensity of each compound using an 8-point scale (where $0=$ no odor detected, 7 $=$ very strong). Further details of procedure have been reported elsewhere. ${ }^{3)}$ Volatile compounds were identified by matching retention indices (RI) ${ }^{4)}$ and mass spectra of samples with those of authentic standards (Aldrich Chemical Co.). Tentative identifications were based on standard MS library data (Hewlett-Packard Co.). The relative abundance of each compound was expressed by the ratio of its total ion peak area to that of an internal standard.

\section{RESULTS}

A total of 104 volatile compounds were detected in wild (68) and cultured sweet smelts including C (78), CA (85), CP (83) and CPA (83) by LLCE/GC-MS method (no data). These compounds were composed mainly of aldehydes (10), ketones (7), alcohols (19), acids (10), esters (6), terpenes (4), aromatic compounds (25) and miscellaneous compounds (23). A total of 33 aroma-active compounds, including 8 aldehydes, 5 alcohols, 2 terpenes, 1 ketone, 1 ester, 1 sulfur containing compound and 15 unknowns, were also detected by $\mathrm{GC} / \mathrm{O}$ in wild and cultured sweet smelts (Table 1). Among 8 aldehydes detected, $(E, Z)$ 2,6-nonadienal and $(E)$-2-nonenal were in highest odor intensities in all samples. In particular, $(E)-2$ nonenal was detected with high odor intensity in wild one, while the odor intensities of $(E, Z)-2,6$ nonadienal in sweet smelts fed diets with $\mathrm{CA}$ and $\mathrm{CP}$ were higher than that of wild one. These compounds contributed to the strong cucumber and melon-like odors and characteristic of the overall aroma of sweet smelt.

Additionally, 3,6-nonadien-1-ol, having a cucumber and/or melon-like odor, was also detected with higher 
Table 1. Aroma-active components in wild and cultured sweet smelts fed with various diets

\begin{tabular}{|c|c|c|c|c|c|c|c|}
\hline \multirow[b]{2}{*}{ Compound $^{2}$} & \multirow[b]{2}{*}{$\mathrm{RI}^{\mathbf{b}}$} & \multicolumn{5}{|c|}{ Mean todor intensity } & \multirow[b]{2}{*}{ Odor description } \\
\hline & & $c^{d}$ & $\mathrm{CA}^{\mathrm{N}}$ & $\mathrm{CP}^{\mathrm{d}}$ & $\mathrm{CPA}^{\mathrm{d}}$ & $\mathrm{N}^{\triangleleft}$ & \\
\hline Ethyl acetate & $<900$ & 2.2 & 4.5 & 3.0 & 3.0 & 1.4 & Sweet, floral \\
\hline 2-Pentanone & 966 & 1.0 & 2.1 & 3.3 & 2.2 & 1,0 & Sweet, wine, floral \\
\hline a-Pinene & 1022 & 2.5 & 3.1 & $\mathrm{Nd}^{\prime}$ & 2.2 & 1.0 & Green, pine \\
\hline Unknown & 1055 & $N d^{r}$ & 4.6 & $\mathrm{Nd}^{\mathrm{t}}$ & 2.6 & 2,1 & Candy, floral \\
\hline Hexanal & 1078 & 1.3 & 2.5 & 2.3 & 2.2 & 4,0 & Green, grassy \\
\hline Unknown & 1120 & $N d^{\mathrm{T}}$ & $\mathrm{Nd}^{\mathrm{r}}$ & $N d^{t}$ & $\mathrm{Nd}^{\prime}$ & 2.1 & Fatty, wet paper \\
\hline B-pinene & 1131 & 1.7 & 2.1 & 1.7 & 2.1 & 1.5 & Plant, pine \\
\hline Unknown & $1141)$ & $\mathrm{Nd}^{\mathrm{r}}$ & $\mathrm{Nd}^{\prime}$ & $\mathrm{Na}^{\mathrm{r}}$ & $\mathrm{Nd}^{\mathrm{r}}$ & 2.3 & Fatty, mcaty \\
\hline Unknown & 1160 & $\mathrm{Nd}^{r}$ & $\mathrm{No} d^{\prime}$ & $\mathrm{Nd}^{\mathrm{I}}$ & 1.3 & 2.2 & Fruity \\
\hline 2-Methyl-2-pentenal & 1177 & $N d^{1}$ & 2.3 & 1.4 & 1.2 & 1.3 & Grassy, moldy \\
\hline 1-Pentcn-3-6) & 1199 & $N d^{\prime}$ & $\mathrm{Nd}^{i}$ & $\mathrm{Nd}^{\mathrm{r}}$ & $\mathrm{Nd}^{\mathrm{r}}$ & 2.5 & Plant, stale \\
\hline 3-Methyl-1-butanol & 1228 & 2,4 & 2.3 & 1.5 & 1.3 & 1.3 & Chocolate \\
\hline Unknown & 1258 & 2.6 & 3.2 & $\mathrm{Nd}^{\mathrm{r}}$ & 4.2 & 2.1 & Soy sauce, savory \\
\hline Unknown & 1273 & 3.0 & $\mathrm{Nd} \mathrm{d}^{\prime}$ & 3.3 & 2.1 & 3.3 & Earthy, mushroom \\
\hline Octanal & 1289 & 1.3 & 5.3 & 2.4 & 3.0 & 2.3 & Sweet, wine, green \\
\hline Unknown & 1327 & 3.2 & 2.5 & 2.2 & 1.6 & 2.2 & Nutty, soy sauce \\
\hline Nonama! & 1388 & 1.1 & 3.2 & 3.5 & 2.4 & 1.4 & Fatty, fishy \\
\hline Unknown & 1413 & $\mathrm{Nd}^{\prime}$ & $\mathrm{Nd}^{\mathrm{I}}$ & $N d^{f}$ & $\mathrm{Nd}^{\mathrm{t}}$ & 4.5 & Sweet, honey \\
\hline Unknown & 1431 & $\mathrm{Nd}^{\prime}$ & 1.2 & 3.5 & $\mathrm{Nd}^{\mathrm{l}}$ & $\mathrm{Nd}^{\mathrm{I}}$ & Sowr, apple cider \\
\hline 1-Octen-3-ol & $144 K$ & 2.2 & 3.1 & 3.2 & 2.2 & 3.2 & Mushroom \\
\hline 1,5-Octudien-3-01 & 1472 & 2.1 & 2.1 & 3.3 & 3.2 & 4.2 & Mctallic, geranium \\
\hline Decanual & 1494 & 3.3 & 3.1 & 3.3 & 3.1 & 3.1 & Oify, fatty \\
\hline Unknoiwn & 1520 & 2.0 & 3.2 & 5.5 & 3.3 & 4.3 & Futty, sweet, nutty \\
\hline (E)-2-runenal & 1554 & 2.7 & 4.2 & 4.5 & 3.6 & 5.2 & Cucumber \\
\hline$(E, Z)-2,6-$ Nonadienal & 1582 & 3.3 & 5.2 & 4.9 & 4.2 & 3.3 & Cucumber, melon \\
\hline Undecanal & 16015 & 2.6 & 2.6 & 3.4 & 2.1 & 1.6 & Fatty, chncolate \\
\hline Unknown & 1713 & $\mathrm{Nd}$ & 2.4 & 3.3 & 2.6 & 1.3 & Cucumber, fatty \\
\hline Unknown & 1740 & 2.7 & 3.6 & 2.4 & 2.5 & 1.4 & Nutty, grainy, fatty \\
\hline $3,6-$ Nonadien- -0 - & 1790 & 2.1 & 4.4 & 4.6 & 3.3 & 3.2 & Cucumber, melon \\
\hline Unksown & 1 (⿻1166 & $\mathrm{Nd}^{\prime}$ & $\mathrm{Nd}^{\mathrm{r}}$ & 3.2 & $\mathrm{Nd}^{\mathrm{f}}$ & 2.6 & Plant \\
\hline Benzothiazole & 1990 & 1.0 & 2.0 & 2.7 & 2.2 & $\mathrm{Nd} \mathrm{l}^{\mathrm{T}}$ & Seaweed \\
\hline Unknown & 2112 & $\mathrm{Nd}^{\mathrm{f}}$ & 2.2 & 3.4 & 2.1 & 2.0 & Floral, sweet \\
\hline Unknown & 2187 & $\mathrm{Nd}^{t}$ & 3.0 & $3.1)$ & 2.10 & $\mathrm{Nd}$ & Fatty, plant \\
\hline
\end{tabular}

${ }^{4}$ Compounds identified by comparison of theit MS, RI and odor propertics with authentic standards.

"Retention index un DB-WAX column. 'Mcan odor intensity from six replications

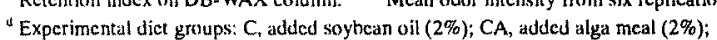
CP; adjded perifia sil ( $2 \%)$; CPA, added alga meal $(2 \%)+$ perilla oil $(2 \%)$; N, wild one. "Odor as perceived during olfactometry. 'No odor detected.

intensity in CA and $\mathrm{CP}$ than in wild one. Unidentified compound $(\mathrm{RI}=1703)$ having cucumber-like odor was also detected in 3.3-1.3 of odor ranges in all samples except for control (C). The $\mathrm{C}_{8}$ alcohols including 1octen-3-ol and 1,5-octadien-3-ol were strongly detected with mushroom and geranium leaf-like odors in wild sweet smelt and followed by CP, CA, CPA and $\mathrm{C}$ in order. However, 2 terpenes having pine and plant odors, $\alpha$ and $\beta$-pinenes, were detected in higher intensities in CA supplemented with alga meal.

\section{DISCUSSION}

In general, the generation of characteristic fish odor involves both enzymic and nonenzymic oxidative mechanism that initiate hydroperoxide formation in fish lipid system. This system is known to be responsible for the formation of volatile compounds, such as short chain carbonyls and alcohols. Furthermore, the characteristic odor of wild smelt was revealed in the viscera and skin, while it was nearly imperceptible in the muscle by many researchers. ${ }^{5,6)}$ Certain volatile nine-carbon aldehydes and alcohols, including $(E)$-2-nonenal, $(E, Z)$-2,6-nonadienal and 3,6-nonadien-1-ol are also derived from PUFAs such as EPA and DHA through lipoxygenase-mediated reaction, and known to act as the key compounds contributing to the characteristic aroma of cucumber and watermelon to the sweet smelt. ${ }^{6)}$ In particular, enzymically derived carbonyls and alcohols such as 1-penten-3-ol, 1-octen-3-ol, 1,5-octadien-3-ol, 3,6nonadien-1ol, $(E)$-2-nonenal, $(E, Z)-2,6$-nonadienal and hexanal were detected with high odor intensities in all samples. Meanwhile, the $\mathrm{C}_{9}$ compounds generated from hydroperoxides, such as $(E)$-2nonenal and $(E, Z)-2,6$-nonadienal, should contribute to the characteristic flavor of sweet smelt with low thresholds, $0.08 \mathrm{ppb}$ and $0.01 \mathrm{ppb}$, respectively. There was no significant difference in odor intensity between wild and cultured sweet smelts on the desirable aroma levels.

From the results on this study, feeding diet supplemented with alga meal or perilla oil is useful for improvement of the flavor quality of cultured sweet smelt.

\section{ACKNOWLEDGMENTS}

This work was supported by Korea Research Foundation Grant (KRF-2000-041-H00004).

\section{REFERENCES}

1. Jeong BY, Moon SK, Jang WS. Fatty acid compositions of wild and cultured sweet smelt Plescoglossus altivelis in Korea and Japan. Proc. Of Scientific Joint Seminar on Develop. of Healthy Sweet Smelt Seeds in Korea and Japan, Tongyeong, Oct. 6-9, Korea, 2000; 45-49.

2. Cha YJ, Kim H, Park SY, Kim SJ, You YJ. Identification of irradiation-induced volatile flavor compounds in beef. $J$. Korean Soc. Food Sci. Nutr., 2000; 29: 1042-1049.

3. Cha $\mathrm{YJ}$, $\mathrm{Kim} \mathrm{H}$, Cadwallader $\mathrm{KR}$. Aroma-active compounds in kimchi during fermentation. J. Agric. Food Chem., 1998; 46: 1944-1953.

4. van den Dool $\mathbf{H}$, Kratz PD. A generalization of the retention index system including linear temperature programmed gas liquid partition chromatography. $J$. Chromatogr., 1963; 11: 463-471.

5. Hirano T, Zhang CH, Morishita A, Suzuki T, Shirai T. ldentificatiob of volatile compounds in ayu fish and feeds. Nippon Suisan Gakkaishi, 1992; 58: 547-557.

6. Josephson DB, Lindsay RC. Enzymic generation of volatile aroma compounds from fresh fish. In: Biogeneration of aroma, Parliament TH, Croteau R (eds), ACS symposium series No.317, 1986; 201-219. 